\title{
PENGARUH KREDIBILITAS KONSELOR TERHADAP SIKAP REMAJA MENGENAI HIV/AIDS DI SUKABUMI
}

\author{
Yayan Zainal Niftah ${ }^{1}$ dan Agus Rahmat ${ }^{2}$ \\ ${ }^{1}$ Humas dan Protokoler KabupatenSukabumi \\ ${ }^{2}$ Universitas Padjadjaran
}

\begin{abstract}
ABSTRAK
Permasalahan remaja yang berkaitan dengan kesehatan reproduksi sering kali berawal dari kurangnya informasi, pemahaman dan kesadaran untuk mencapai keadaan sehat secara reproduksi. Banyak sekali halhal yang berkaitan dengan hal ini, mulai dari pemahaman mengenai perlunya pemeliharaan kebersihan alat reproduksi, pemahaman mengenai proses-proses reproduksi serta dampak dari perilaku yang tidak bertanggung jawab seperti kehamilan tak diinginkan, aborsi, penularan penyakit menular seksual termasuk HIV. Penelitian ini bertujuan untuk mengetahui pengaruh kredibilitas konselor HIV/AIDS di Kabupaten Sukabumi terhadap sikap remaja tentang HIV/AIDS. Variabel penelitian yang dianalisis dalam penelitian ini adalah keahlian, kepercayaan, daya tarik pesan terhadap sikap, dengan populasi remaja 6 Desa yang berada di Kabupaten Sukabumi. Teknik sampel menggunakan strata proposional. Partisipan penelitian atau sampel yang terpilih sebanyak 401 orang remaja. Penelitian ini menggunakan analisis jalur yang merupakan analisis untuk mengetahui seberapa besar pengaruh variabel bebas terhadap variabel terkait, baik bersifat parsial maupun pengaruh bersifat total. Hasil penelitian menunjukkan bahwa keahlian komunikator dalam menyampaikan pesan tentang bahaya HIV/AIDS telah mampu menambah pengetahuan remaja di Kecamatan Sukabumi, juga dapat menimbulkan kepercayaan remaja terhadap Konselor HIV/AIDS serta kesediaan untuk menjauhi perilaku berisiko seperti menggunakan narkoba dan seks bebas dan kesediaan untuk mengiformasikan kepada orang lain tentang bahaya HIV/AIDS. Dari hasil penelitian ini menunjukkan bahwa agar penderita lebih terbuka dalam menceritakan kronologis tentang penyakit yang diidapnya serta penularannya, yang harus dilakukan adalah mempertinggi kredibilitas komunikator atau konselor HIV/AIDS.
\end{abstract}

Kata-kata Kunci: Kredibilitas komunikator, pesan, keahlian, kepercayaan, sikap

\section{THE INFLUENCE OF HIVIAIDS COUNSELLOR'S CREDIBILITY ON TEENAGE PERSPECTIVES ON HIVIAIDS IN SUKABUMI REGENCY}

\begin{abstract}
Teenage problem connected to reproduction health is often linked to lack of information, understanding, and awareness toachieve a high state of reproduction health. There are a lot of things connected to reproduction health, with starting point in understanding the need of maintaining the sanitary of reproduction organ; understanding the reproduction process; and affected behaviour such as unwanted pregnancy, abortion, sexually transmitted diseases such as HIV. The purpose of this research is to explore the influence of HIVI AIDS counsellor's credibility on teenage perspectives on HIVIAIDS in Sukabumi Regency. Research variable being analysed are skill, trustworthiness, message appealing on audience's perspective. The population for this research are teenagers in six villages in Sukabumi Regency. Sampling technique is proportionate strata sampling. Samples chosen consists of 401 teenagers. Path analysis is being used to examine level of free variable on associated variable, whether partially or complete influence. The result shows that communicator skills in delivering the message of HIV/AIDS are able to increase the knowledge of teenager on the danger of HIV/AIDS. It is also resulted in the increase of trust on HIV/AIDS counsellor along with the willingness to avoid risky behaviour such as drugs and free sex. Furthermore, it is culminated in the willingness to inform other people on the HIV/AIDS dangerous effect. Results also shown the fact that people infected ought to be open on the chronology of the diseases and its spreads, this can be done by increasing communicator on HIVI AIDS (Councellors) credibility.
\end{abstract}

Keywords: Communicator's credibility, messages, expertise, trust, attitudes

Korespondensi: Yayan Zainal Niftah, M.I.Kom. Humas dan Protokoler Kabupaten Sukabumi, Jalan Siliwangi No.10, Sukabumi. Email: yayanzn80@yahoo.com 


\section{PENDAHULUAN}

Pembangunan kesehatan merupakan bagaian dari pembangunan nasional yang bertujuan meningkatkan kesadaran dan kemampuan hidup sehat bagi setiap orang agar terwujud derajat kesehatan setinggi tingginya tanpa membedakan ras, agama, jenis kelamin, politik yang dianut, dan tingkat sosial ekonominya (Peraturan Pemerintah RI, 2012), dan menjadi keniscayaan pencapaian derajat kesehatan yang dimaksud membutuhkan partisipasi masyarakat. Banyak fakta yang menunjuk mengenai kesadaran atas pentingnya partisipasi masyarakat dalam pencapaian derajat kesehatan, seperti termuat dalam landasan WHO di tahun 1948 sampai Piagam Otawa di tahun 1986 (WHO, 2004).

Salah satu kelompok sasaran dalam pembangunan kesehatan adalah kelompok remaja. Kelompok ini menjadi perhatian yang tinggi terkait dengan jumlah yang paling besar (lihat Data Penduduk Sasaran Program Kesehatan tahun 2007/2011) dan kelompok usia yang rentan dengan resiko penyakit karena lingkungan sosial seperti pergaulan sex bebas dan kesehatan reproduksi.

Permasalahan remaja yang berkaitan dengan kesehatan reproduksi sering kali berawal dari kurangnya informasi, pemahaman dan kesadaran untuk mencapai keadaan sehat secara reproduksi. Banyak sekali halhal yang berkaitan dengan hal ini, mulai dari pemahaman mengenai perlunya pemeliharaan kebersihan alat reproduksi, pemahaman mengenai proses-proses reproduksi serta dampak dari perilaku yang tidak bertanggung jawab seperti kehamilan tak diinginkan, aborsi, penularan penyakit menular seksual termasuk HIV. Kesehatan reproduksi merupakan suatu keadaan kesehatan yang sempurna baik secara fisik, mental, dan sosial dan bukan semata-mata terbebas dari penyakit atau kecacatan dalam segala aspek yang berhubungan dengan sistem reproduksi, fungsi serta prosesnya. Sedangkan kesehatan reproduksi menurut WHOladalah suatu keadaan fisik, mental dan sosial yang utuh, bukan hanya bebas dari penyakit atau kecacatan dalam segala aspek yang berhubungan dengan sistem reproduksi, fungsi serta prosesnya.

Di kalangan remaja perilaku seksual semakin memperihatinkan. Data Departemen Kesehatan Republik Indonesia pada tahun
2006 menunjukkan jumlah remaja umur 10 19 tahun di Indonesia sekitar 43 juta $(19,61 \%)$ dari total jumlah penduduk. Sekitar 1 juta remaja pria $(5 \%)$ dan 200 ribu remaja wanita (1\%) secara terbuka menyatakan bahwa mereka pernah melakukan hubungan seksual. Di Indonesia diperkirakan ada 1 juta remaja yang mengalami kehamilan di luar nikah, sedangkan di seluruh dunia diperkirakan 15 juta remaja setiap tahunnya hamil, 60\% diantaranya hamil di luar nikah (Hidayat dalam Tinceuli, 2010).

Hasil survei yang dilakukan oleh Komisi Perlindungan Anak Indonesia (KPAI) tahun 2012 terhadap 4.726 Responden dari Siswa SMP/ SMP di 17 kota besar di Indonesia didapatkan hasil bahwa $62,7 \%$ Siswi tidak perawan, dan sebanyak 21,2\% mengaku pernah melakukan aborsi. Dengan kata lain sekitar 2.963 dari 4.726 siswa pernah melakukan hubungan seksual. Departemen Kesehatan Republik Indonesia (2010/2011) mengungkapkan bahwa dari 1.189 remaja belum menikah (berusia 13-19 tahun) di Jawa Barat dan 922 remaja di Bali, ditemukan 7\% remaja perempuan di Jawa Barat dan 5\% di Bali mengakui pernah mengalami kehamilan.

Hasil penelitian Dinas Kesehatan Sukabumi, sepanjang tahun 2007, 30\% Pelajar Sukabumi diduga melakukan seks bebas. Sekretaris Komisi Penanggulangan AIDS Daerah (KPAD) menyebutkan bahwa perilaku seks bebas ini telah melibatkan pelajar yang bukan hanya berasal dari tingkat SMU saja tapi juga kalangan pelajar SMP.

Data dari Lembaga Swadaya Masyarakat (LSM) peduli HIV/ AIDS, Jaringan Aksi Perubahan Indonesia (JAPI) yang dikutip dari Antara, Rabu (28/5 2015) menyebutkan jumlah pengidap HIV/ AIDS di Kota dan Kabupaten Sukabumi adalah 1.067 jiwa, dengan rincian kota sukabumi sebanyak 760 jiwa dan kab. Sukabumi sebanyak 307 jiwa. Selain itu, data dari Komisi Penanggulangan HIV/ AIDS Kabupaten Sukabumi diperoleh data bahwa setiap tahunnya kasus baru HIV/ AIDS di kabupaten sukabumi mengalami kenaikan yakni 14 kasus baru pada tahun 2011, 22 kasus baru tahun 2012, 89 kasus baru tahun 2013 dan data terakhir selama periode januari sampai mei 2014 ditemukan 35 kasus baru HIV/ AIDS, dengan rincian penyebab dari 35 kasus pada tahun 2014 sebanyak 60\% disebabkan oleh perilaku seksual.

Komunikasi yang baik sangat dibutuhkan di 
dalam dunia kesehatan, terutama bila berkaitan dengan penyakit yang dapat menyebabkan kematian seperti HIV/AIDS. Jika seorang dokter, perawat atau konselor tidak menyampaikan pesan tentang HIV/AIDS dengan baik, maka pasien tersebut dapat menjadi stress dan lebih parah lagi mempunyai kecenderungan untuk bunuh diri. Maka disinilah peran konselor HIV/ AIDS sangat dibutuhkan, karena sampai saat ini penyakit HIV/AIDS ini belum ada obat yang dapat menyembuhkan penderita HIV/AIDS. Oleh karena itu kegiatan koseling sebaiknya dilakukan agar seorang penderita HIV/AIDS mempunyai tempat berbagi atau mengurangi bebannya. Berdasarkan latar belakang penelitian di atas, maka perumusan masalah dalam penelitian ini: "Seberapa Besar Pengaruh Kredibilitas Konselor HIV/ AIDS terhadap Sikap Remaja di Kecamatan Sukabumi, Kabupaten Sukabumi”.

Guna memudahkan analisa, selanjutnya masalah tersebut dirinci menjadi tiga aspek, yaitu: pengaruh keahlian Konselor HIV/ AIDS dalam kegiatan penyuluhan HIV/AIDS terhadap pengetahuan, perasaan dan perilaku Remaja; pengaruh kepercayaan kepada Konselor HIV/ AIDS dalam kegiatan penyuluhan HIV/ AIDS terhadap pengetahuan, perasaan dan perilaku Remaja; dan pengaruh daya tarik Konselor HIV/ AIDS dalam kegiatan penyuluhan HIV/ AIDS terhadap pengetahuan, perasaan dan perilaku Remaja.

Penelitian ini berpangkal pada teori Behaviorisme, teori ini memandang bahwa pada hakekatnya manusia ditentukan oleh lingkungannya, sehingga segala sikap; pendapat; dan perilaku individu dibentuk dan dipengaruhi oleh lingkungan dimana ia berada (Rakhmat, 2008: 20-25). Dalam teori ini perilaku diasumsikan terjadi sebagai hasil interaksi antara manusia dengan lingkungan, atau prilaku; sikap; dan pendapat seseorang diasumsikan sebagai hasil dari interaksi antara dirinya dengan lingkungannya. Dengan demikian, behaviorisme membahas bagaimana lingkungan mempengaruhi manusia dan seberapa besar lingkungan mempengaruhi tindakan-tindakan manusia.

Guna lebih mengoperasionalkan dalam penelitian, selanjutnya teori yang dipakai pijakan peneliti adalah teori kredibilitas komunikator. Kredibilitas atau kepercayaan atau dapat dipercaya menurut Tseng \& Fogg
(1999) dalam Susanne Furman (2009), sebagai sebuah teori dalam komunikasi yang pertama dipopulerkan oleh Hovland, Janis and Kelly (dalam Umeogu, 2012). Teori kredibilitas berpangkal pada pemikiran bahwa penerimaan informasi dan gagasan sebagian didasarkan pada siapa yang mengatakannya (Epega, 2008), teori ini menempatkan bagaimana berartinya sumber (komunikator) bagi efektivitas komunikasi. Dalam perkembangan selanjutnya kredibilitas ini telah diberi banyak nama seperti: etos, prestise, karisma, citra, atau kredibilitas sumber yang paling sering" (Berlo, Lemert, \& Mertz, dalam Epega (2008).

Pada awalnya, studi tentang kredibilitas sumber (Hovland \& Weiss dalam Epega, 2012) berpangkal pada dua aspek utama yakni keahlian dan kepercayaan dalam perkembangan selanjutnya ilmuwan menemukan kembali aspek lainnya yaitu daya tarik. Oleh karenanya McC Roskey mengidentifikasi bahwa sumber kredibilitas menjadi tiga yaitu: (i) keahlian, (ii) kepercayaan, dan (iii) daya tarik (Epega: 2012).

Apa yang diungkap Epega (2012) sama dengan yang dikemukakan Rakhmat (2008), bahwa faktor kredibilitas meliputi keahlian dan kepercayaan serta daya tarik yang berupa fisik, kemampuan berkomunikasi, kesamaan juga ganjaran. Selain teori kredibilitas teori yang penting dalam penelitian ini adalah teori sikap. Teori sikap yang ada sekarang telah berkembang dari teori awal atau teori klasik seperti teori penghakiman sosial, Sherif, Sherif, \& Nebergall, 1965; teori integrasi informasi, Anderson, 1981 (dalam Kumkale, 2010).

Sikap dapat diartikan sebagai evaluasi positif atau negatif terhadap orang, objek, kejadian, atau gagasan. Dalam kaitan dengan kesehatan, sikap dianggap sebagai hal yang demikian penting mengingat salah satu faktor yang mempengaruhi kesehatan fisik adalah sikap. Beberapa kajian menunjukkan bahwa sikap yang dipegang seseorang mengenai seseorang, kejadian, atau gagasan tertentu memengaruhi bagaimana kita berperilaku.

Relasi pemikiran yang didapat dari pemikian para ahli nampak bahwa guna mewujudkan perilaku sehat dari remaja maka perlu di bentuk ataupun dirubah melalui sikap oleh orangorang yang memiliki kredibilitas. Berdasar atas apa yang diungkap maka gambaran mengenai logika berpikir penelitian ditunjukan melalui Gambar 1. 


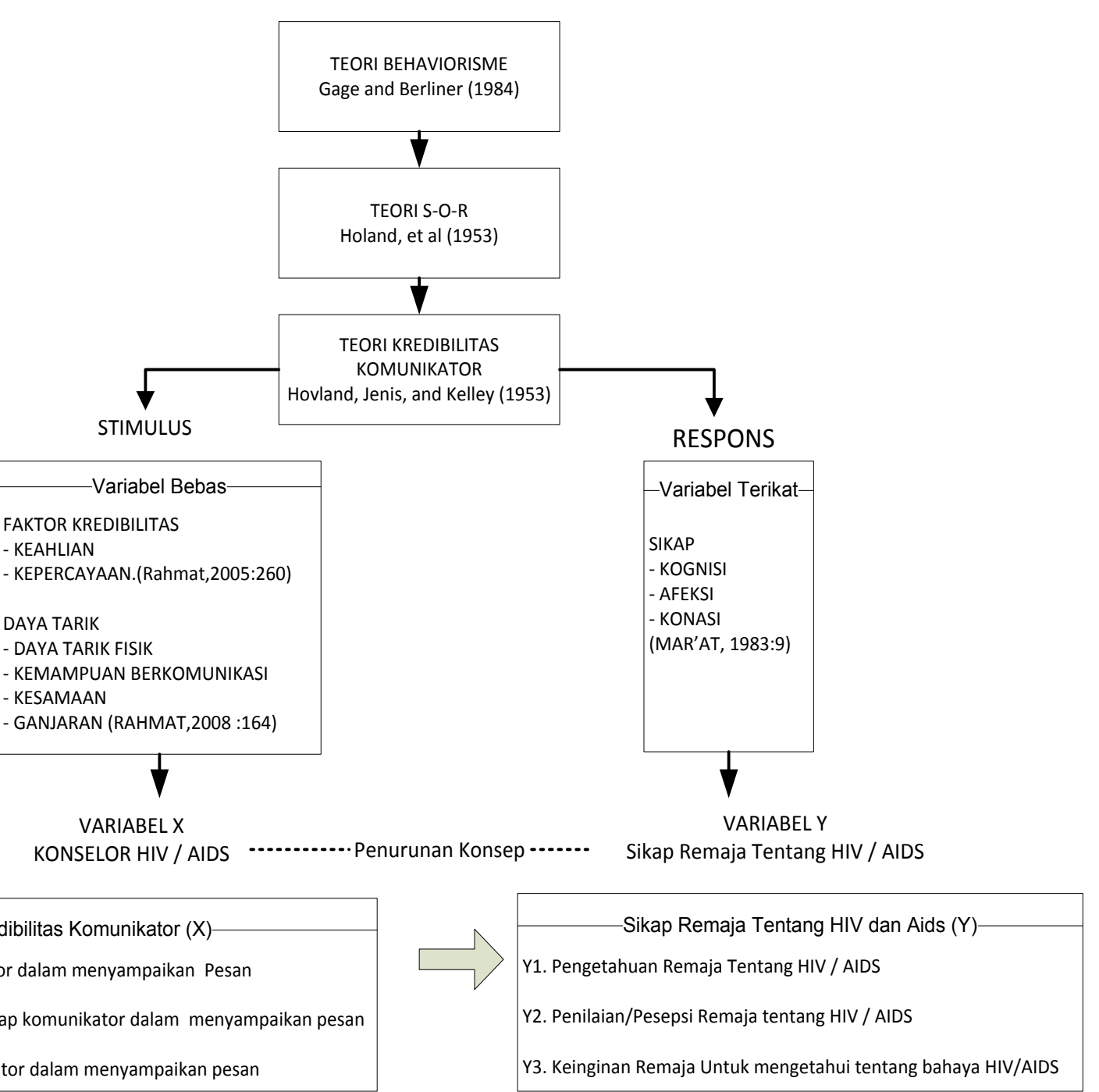

\section{Gambar 1 Kerangka kerja \& berpikir penelitian}

Berdasar pemikiran para ahli seperti sudah dikemukakan sebelumnya dan dipetakan melalui kerangka penelitian, selanjutnya peneliti menentukan dimensi penelitian dari setiap variabel, yang ditunjukan melalui tabel 1 .

\section{METODE PENELITIAN}

Penelitian ini dilakukan dengan menggunakan pendekatan kuantitatif dan menggunakan metode studi deskriptif yang diarahkan untuk memecahkan masalah dengan cara memaparkan atau menggambarkan apa adanya hasil penelitian. Dalam upaya menjawab tujuan penelitian, penelitian ini menggunakan metode survei yaitu suatu penelitian yang digunakan untuk menjelaskan hubungan kausal dan pengujian hipotesis. Masri S dalam Riduwan (2010: 207) menjelaskan penelitian survei dapat digunakan untuk maksud (1) penjajagan (eksploratif), (2) deskriptif, (3) penjelasan (eksplanatory atau confirmatory), yakni menjelaskan hubungan kausal dan pengujian hipotesis; (4) evaluasi, (5) prediksi atau meramalkan kejadian tertentu di masa yang akan datang, (6) penelitian operasional, dan (7) pengembangan indikator-indikator sosial. Studi yang dilakukan adalah studi kepustakaan dan studi lapangan. Teknik pengumpulan data menggunakan angket/kuesioner.

Penyebaran kuesioner dilakukan kepada responden yaitu remaja di Kecamatan Sukabumi, dilakukan oleh konselor HIV/AIDS, kader WPA (Warga Peduli AIDS) dan PIKM (Pusat Informasi Kesehatan Masyarakat). Remaja yang menjadi responden dalam penelitian ini berjumlah 401 orang yang berasal dari beberapa desa sebagai daerah yang terpilih.

Rangkaian berpikir mulai populasi sampai penentuan sampel, didasarkan data Tabel 2. 
Tabel 1 Variabel Penelitian

\begin{tabular}{|c|c|c|c|c|}
\hline Variabel & Sub-Variabel & Indikator & Pernyataan & Skala \\
\hline \multirow[b]{3}{*}{ Independent } & & $\begin{array}{l}\text { 1. Latar Belakang } \\
\text { Komunikator }\end{array}$ & $\begin{array}{l}\text { Konselor mempunyai latar belakang yang } \\
\text { baik. }\end{array}$ & Ordinal \\
\hline & Keahlian & 2. Pengetahuan & $\begin{array}{l}\text { Konselor mempunyai pengetahuan yang } \\
\text { baik tentang HIV/AIDS. }\end{array}$ & Ordinal \\
\hline & Kepercayaan & 1. Dapat dipercaya & $\begin{array}{l}\text { Konselor dapat dipercaya dalam } \\
\text { menyampaikan pesan tentang HIV/AIDS }\end{array}$ & Ordinal \\
\hline \multirow{3}{*}{ Kredibilitas } & & 2. Niat Baik & $\begin{array}{l}\text { Konselor mempunyai niat baik dalam } \\
\text { menyampaikan pesan tentang HIV/AIDS }\end{array}$ & Ordinal \\
\hline & Daya Tarik & 1. Daya Tarik Fisik & $\begin{array}{l}\text { Konselor mempunyai daya tarik fisik } \\
\text { yang baik. }\end{array}$ & Ordinal \\
\hline & & $\begin{array}{l}\text { 2. Daya Tarik } \\
\text { Penyampaian Pesan }\end{array}$ & $\begin{array}{l}\text { Konselor mempunyai daya tarik } \\
\text { penyampaian pesan yang baik. }\end{array}$ & Ordinal \\
\hline Variabel & Sub-Variabel & Indikator & Pernyataan & Skala \\
\hline \multirow{6}{*}{$\begin{array}{l}\text { Dependent } \\
\text { (Variabel Y): }\end{array}$} & & $\begin{array}{l}\text { Pengetahuan tentang } \\
\text { HIV/ AIDS }\end{array}$ & $\begin{array}{l}\text { Bertambahnya pengetahuan tentang HIV/ } \\
\text { AIDS dari konselor. }\end{array}$ & Ordinal \\
\hline & Pengetahuan & $\begin{array}{l}\text { Pemahaman tentang } \\
\text { HIV/ AIDS }\end{array}$ & $\begin{array}{l}\text { Bertambahnya pemahaman tentang HIV/ } \\
\text { AIDS dari konselor. }\end{array}$ & Ordinal \\
\hline & \multirow[t]{2}{*}{ Perasaan } & $\begin{array}{l}\text { Merasa penting } \\
\text { mengetahui tentang } \\
\text { bahaya HIV/ AIDS }\end{array}$ & $\begin{array}{l}\text { Merasa penting mengetahui bahaya HIV/ } \\
\text { AIDS setelah bertemu dengan konselor. }\end{array}$ & Ordinal \\
\hline & & $\begin{array}{l}\text { Merasa bahwa yang } \\
\text { terkena HIV/AIDS } \\
\text { mempunyai tempat } \\
\text { untuk konseling. }\end{array}$ & $\begin{array}{l}\text { Merasa ada tempat untuk konseling bagi } \\
\text { orang-orang yang terkena HIV/AIDS }\end{array}$ & Ordinal \\
\hline & \multirow[b]{2}{*}{ Perilaku } & $\begin{array}{l}\text { Menjauhkan diri } \\
\text { bahayanya HIV/ } \\
\text { AIDS. }\end{array}$ & $\begin{array}{l}\text { Menjauhkan diri dari perilaku yang dapat } \\
\text { terkena oleh HIV/AIDS }\end{array}$ & Ordinal \\
\hline & & $\begin{array}{l}\text { Menyebarkan } \\
\text { pengetahuan tentang } \\
\text { HIV/ AIDS kepada } \\
\text { orang lain. }\end{array}$ & $\begin{array}{l}\text { Menyebarkan pengetahuan seputar HIV/ } \\
\text { AIDS kepada orang lain. }\end{array}$ & Ordinal \\
\hline
\end{tabular}

Tabel 2 Jumlah Populasi Penelitian

\begin{tabular}{ccccc}
\hline No & Desa & Jumlah Penduduk & Jumlah Laki-laki & Jumlah Perempuan \\
\hline 1 & Parungseah & 10.646 & 5.519 & 5127 \\
\hline 2 & Sundajaya Girang & 7.868 & 3.999 & 3.869 \\
\hline 3 & Karawang & 6.837 & 3.536 & 3.301 \\
\hline 4 & Warnasari & 8.332 & 4.270 & 4.062 \\
\hline 5 & Sukajaya & 7.023 & 3.674 & 3.349 \\
\hline 6 & Perbawati & 6.871 & 3.524 & 3.347 \\
\hline & Total & 47.577 & 24.522 & 23.055 \\
\hline
\end{tabular}


Jumlah penduduk di wilayah Kecamatan Sukabumi dari total 6 desa yang ada, penduduk yang berjenis kelamin Laki-laki ada 24.522 jiwa, sedangkan perempuan ada 23.055 jiwa sehingga secara keseluruhan penduduk di wilayah Kecamatan Sukabumi berjumlah 47.577 jiwa.

Berdasarkan umur, penduduk yang berumur di antara 15-24 tahun berjumlah 8.735 jiwa. Jumlah ini selanjutnya yang disebut sebagai populasi penelitian. Sesudah diperoleh mengenai populasi dan sebaran usia, peneliti juga mempertimbangkan jenis kelamin sebagai aspek yang diperhatikan untuk penelitian ini dengan hasil seperti ditunjukkan pada tabel 3.

Tabel 3 Jumlah Penduduk yang berusia 1524 tahun

\begin{tabular}{cc}
\hline Jenis Kelamin & Jumlah \\
\hline Laki-laki & 4.542 \\
\hline Perempuan & 4.193 \\
\hline Jumlah & 8.735 \\
\hline
\end{tabular}

Sumber: Profil kependudukan BKKBD

Kabupaten Sukabumi 2015

Hasil akhir atas sebaran penduduk usia remaja dan jenis kelamin di wilayah kajian diperoleh sampel pada Tabel 4.

Tabel 4 Jumlah Sampel per-Desa

\begin{tabular}{llllll}
\hline No & Desa & $\begin{array}{l}\text { Jumlah } \\
\text { Penduduk }\end{array}$ & $\begin{array}{l}\text { Jumlah } \\
\text { Sampel }\end{array}$ & $\begin{array}{l}\text { Jumlah } \\
\text { sampel } \\
\text { Laki- } \\
\text { laki }\end{array}$ & $\begin{array}{l}\text { Jumlah } \\
\text { sampel } \\
\text { perem- } \\
\text { puan }\end{array}$ \\
\hline 1 & Parungseah & 10.646 & 90 & 45 & 45 \\
\hline 2 & $\begin{array}{l}\text { Sundajaya } \\
\text { Girang }\end{array}$ & 7.868 & 66 & 33 & 33 \\
\hline 3 & Karawang & 6.837 & 58 & 29 & 29 \\
\hline 4 & Warnasari & 8.332 & 70 & 35 & 35 \\
\hline 5 & Sukajaya & 7.023 & 59 & 30 & 29 \\
\hline 6 & Perbawati & 6.871 & 58 & 29 & 29 \\
\hline & Total & 47.577 & 401 & 201 & 200 \\
\hline
\end{tabular}

\section{HASIL DAN PEMBAHASAN}

Peneliti mengukur keandalan dari alat ukur yang sudah dibangun dan disusun berdasar pada teori-teori para ahli melalui uji validitas dan reliabilitas dengan hasil yang ditunjukkan oleh Tabel 5.

\section{Tabel 5 Analisis Validitas}

\begin{tabular}{llll}
\hline $\begin{array}{l}\text { No } \\
\text { Pernyataan }\end{array}$ & R hitung & R tabel & Keterangan \\
\hline 1 & $.724^{* *}$ & 0.349 & Valid \\
\hline 2 & $.744^{* *}$ & 0.349 & Valid \\
\hline 3 & $.366^{*}$ & 0.349 & Valid \\
\hline 4 & $.738^{* *}$ & 0.349 & Valid \\
\hline 5 & $.650^{* *}$ & 0.349 & Valid \\
\hline 6 & $.637^{* *}$ & 0.349 & Valid \\
\hline 7 & $.692^{* *}$ & 0.349 & Valid \\
\hline 8 & $.701^{* *}$ & 0.349 & Valid \\
\hline 9 & $.584^{* *}$ & 0.349 & Valid \\
\hline 10 & $.560^{* *}$ & 0.349 & Valid \\
\hline 11 & $.498^{* *}$ & 0.349 & Valid \\
\hline 12 & $.383^{*}$ & 0.349 & Valid \\
\hline
\end{tabular}

Secara umum penelitian ini ingin mengetahui besarnya pengaruh kredibilitas komunikator dalam hal ini adalah kanselor HIV/AID, dengan sikap remaja atas HIV dan IADs. Namun demkian penelitian inipun memerinci variabel kredibilitas atas beberapa dimensi sebagai mana dikemukakan para ahli. Berdasarkan atas hal ini maka pengujian statistik atas penelitian dilakukan secara simultan dan secara parsial.

Uji statistik secara simultas atas pengaruh kredibilitas terhadap sikap remaja mengenai HIV/AIDS adalah sebagai berikut:

Tingkat signifikasi yang digunakan adalah $\alpha=5 \%$

Uji statistik yang dilakukan adalah:

$$
\begin{aligned}
& \mathrm{F}=\frac{(n-k-1) \sum_{i=1}^{n} \text { Pyixi Ryxi }}{\mathrm{k}\left\{1-\sum_{i=1}^{n} \text { Pyixi Ryxi }\right\}} \\
& \mathrm{F}=\frac{(71.5-3-1) \times 0.715}{3\{1-0.715\}}=52.324
\end{aligned}
$$

Uji statistik diatas mengikuti distribusi F-Snodecor dengan $\alpha=5 \%$, derajat kebebasan $\mathrm{db} 1=3$ dan $\mathrm{db} 2=71.5-3-1=67.5$, diperoleh $\mathrm{F}$ tabel $=2.74$. 
Tabel 6 Pengujian Secara Simultan

\begin{tabular}{lllll}
\hline $\begin{array}{l}\text { Hipotes is } \\
\text { Alternatif }\end{array}$ & $\begin{array}{l}\mathrm{F} \\
\text { Hitung }\end{array}$ & $\begin{array}{l}\mathrm{F} \\
\text { Tabel }\end{array}$ & Keputusan & Kesimpulan \\
\hline X1, X2 dan & 52.324 & 2.74 & $\mathrm{H}_{0}$ ditolak & Signifikan \\
X3 secara & & & & \\
S i m u 1 t a n & & & & \\
berpengaruh & & & & \\
kepada Y & & & & \\
\hline
\end{tabular}

Tabel 6 menunjukkan bahwa $\mathrm{F}$ hitung $>\mathrm{F}$ tabel $(52.324>2.74)$.Seseuai dengan kriteria, hasilnya menunjukkan bahwa uji simultan menolakH0.Artinya Keahlian, Kepercayaan dan Daya tarik secara bersama-sama berpengaruh signifikan kepada sikap remaja terhadap HIV/ AIDS di Kabupaten Sukabumi.

Uji statistik selanjutnya dilakukan secara parsial. Dimensi kredibilitas pertama dari beberapa ahli adalah keahlian terhadap sikap: $\alpha=5 \%$

Tingkat signifikasi yang digunakan adalah berikut:

Uji Statistik yang digunakan adalah sebagai

$$
\begin{aligned}
& t=\frac{\text { Pyx1 }}{\sqrt{\frac{(1-R 2 Y x 1 \times 2) \text { CRii }}{(n-k-1)}}} \\
& \text { thitung }=\frac{0.254}{\sqrt{\frac{(1-0.715) 1.372}{(71.5-3-1)}}}
\end{aligned}
$$

Thitung $=3.152$

Berdasarkan atas hasil hitung diperoleh bahwa dalam distribusi t dengan $\alpha=5 \%$ untuk pengujian dua pihak dan $\mathrm{db}=71.5-3$ $1=67.5$ diperoleh nilai $\mathrm{t}$ tabel sebesar 1.995. dari perhitungan diatas dapat kita lihat bahwa $t$ hitung $>t$ tabel $(3.152>1.995)$ sehingga sesuai dengan kriteria uji parsial adalah tolak $\mathrm{H} 0$, artinya Keahlian secara parsial berpengaruh secara signifikan terhadap Sikap, maka dengan demikian semakin ahli seorang konselor maka akan semakin meningkat sikap remaja terhadap HIV/AIDS.

Selanjutnya pengujian statistik kepercayaan terhadap sikap dilakukan sebagai berikut: $\alpha=5 \%$

Tingkat signifikasi yang digunakan adalah

Uji Statistik yang digunakan adalah sebagai berikut:

$$
t=\frac{\text { Pyx1 }}{\sqrt{\frac{(1-R 2 Y \times 1 \times 2) C R i i}{(n-k-1)}}}
$$

$$
\text { thitung }=\frac{0.375}{\sqrt{\frac{(1-0.715) 1.415}{(71.5-3-1)}}}
$$

Thitung $=4.341$

Berdasarkan hasil perhitungan pada $\mathrm{t}$ dengan $\alpha=5 \%$, untuk pengujian dua pihak dan $\mathrm{db}=71.5-3-1=67.5$ diperoleh nilai $\mathrm{t}$ tabel sebesar 1.995. dari perhitungan diatas dapat kita lihat bahwa $t$ hitung $>\mathrm{t}$ tabel $(4.341>1.995)$ sehingga sesuai dengan kriteria uji parsial adalah tolak H0, artinya Kepercayaan secara parsial berpengaruh secara signifikan terhadap Sikap, maka dengan demikian semakin dipercayai seorang konselor maka akan semakin meningkat sikap remaja terhadap HIV/AIDS.

Pengujian statistik selanjutnya adalah pengujian yang dilakukan atas daya tarik terhadap sikap yang langkah dan hasilnya sebagai berikut:

Tingkat signifikasi yang digunakan adalah $\alpha=5 \%$

Uji Statistik yang digunakan adalah sebagai berikut:

$$
\begin{aligned}
& t=\frac{\text { Pyx1 }}{\sqrt{\frac{(1-R 2 Y x 1 \times 2) C R i i}{(n-k-1)}}} \\
& \text { thitung }=\frac{0.481}{\sqrt{\frac{(1-0.715) 1.266}{(71.5-3-1)}}}
\end{aligned}
$$

Thitung $=6.450$

Hasil perhitungan menunjukkan bahwa pada t dengan $\alpha=5 \%$, maka untuk pengujian dua pihak dan $\mathrm{db}=71.5-3-1=67.5$ diperoleh nilai $t$ tabel sebesar 1.995. dari perhitungan diatas dapat kita lihat bahwa $\mathrm{t}$ hitung $>\mathrm{t}$ tabel $(6.450>1.995)$ sehingga sesuai dengan kriteria uji parsial adalah tolak H0, artinya Daya Tarik secara parsial berpengaruh secara signifikan terhadap Sikap, maka dengan demikian semakin besar daya tarik seorang konselor maka akan semakin meningkat sikap remaja terhadap HIV/ AIDS.

Secara ringkas, hasil pengujian parsial atas dimensi kredibilitas yang mencakup atas keahlian, kepercayaan dan daya tarik dapat diringkas dalam Tabel 7. 
Tabel 7 Pengujian Secara Parsial

\begin{tabular}{lllllll}
\hline No & $\begin{array}{l}\text { Hipote- } \\
\text { sis }\end{array}$ & $\begin{array}{l}\text { Koe- } \\
\text { fisien } \\
\text { Jalur }\end{array}$ & $\begin{array}{l}\mathrm{T} \\
\text { Hitung }\end{array}$ & $\begin{array}{l}\mathrm{T} \text { tabel } \\
\text { tusan }\end{array}$ & $\begin{array}{l}\text { Kepu- Kesimpu- } \\
\text { lan }\end{array}$ \\
\hline 1 & $\mathrm{P}_{\mathrm{y} \times 1}=0$ & 0.243 & 3.152 & 1.995 & $\begin{array}{l}\mathrm{H}_{0}= \\
\text { Ditolak }\end{array}$ & Signifikan \\
\hline 2 & $\mathrm{P}_{\mathrm{yx2}}=0$ & 0.375 & 4.341 & 1.995 & $\begin{array}{l}\mathrm{H}_{0}= \\
\text { Ditolak }\end{array}$ \\
\hline 3 & $\mathrm{P}_{\mathrm{y} \times 3}=0$ & 0.481 & 6.450 & 1.995 & $\begin{array}{l}\mathrm{H}_{0}=\text { Signifikan } \\
\text { Ditolak }\end{array}$ \\
\hline
\end{tabular}

Dari tabel 7 dapat kita ketahui bahwa nilai $t$ hitung untuk variabel X1, X2 dan X3 lebih besar dari $t$ tabel, ini berarti bahwa variabel $\mathrm{X} 1, \mathrm{X} 2$ dan X3 memberikan pengaruh yang signifikan terhadap Y. Berdasar pada hasil penelitian yang dilakukan nampak bahwa besarnya pengaruh kredibilitas sumber tidak hanya ditunjukan pada abad 20 (perang dunia kedua) saja, sampai saat ini teori kredibilitas tetap menunjukkan konsistensinya, Umeogu (2012) menyebutnya sebagai teori yang memiliki tingkat konsistensi yang tinggi.

Dalam kajian literatur yang ada teori kredibilitas masuk sebagai model faktor karena lebih pada membantu menentukan dan memahami sejauh mana penerima menilai sumber sebagai kredibel, bukan sejauh mana komunikator memenuhi harapan khalayak atau mengkaji pada apa yang dilakukan khalayak. Sesungguhnya kredibilitas komunikator pada intinya adalah kesan yang dibentuk oleh komunikate tentang kemampuan komunikator (Kosasih, Setianti, \& Wahyudin, 2017).

Sebagai konsekuensi dari penelitian ini maka menjadi keniscayaan, bagi pemerintah khususnya kabupaten Sukabumi dalam malakukan pencegahan penanggulangan HIV/ AIDS sebagai bagian dari pembangunan kesehatan Kabupaten Sukabumi telah menjadi bagian dalam Renacana Pembangunan Jangka Panjang (RPJP) Kabupaten Sukabumi tahun 2005-2025, Rencana Pembangunan Jangka Menengah Daerah Kabupaten Sukabumi Tahun 2010-2015. Maksud dilaksanakannya pencegahan dan penangulangan HIV dan AIDS pada populasi kunci dan populasi umum melalui penyediaan dan penyebarluasan informasi serta menciptakan suasana kondusif, penyediaan pelayanan perawatan, dukungan dan pengobatan kepada ODHA secara konprehensif dengan meningkatkan peran masyarakat dan pengembangan kemitraan, menempatkan komunikator, penyuluh ataupun konsultan kesehatan yang memiliki kredibilitas, dan tidak lagi menyandarkan kegiatan pada komunikator yang mendasarkan diri hanya sekedar tugas rutin. Adapun ciri-ciri khas seseorang akan membentuk kredibilitas diri seorang (Yodiansyah, 2017).

Tidak salah mengangkat seorang dokter untuk jadi penyluh kesehatan masyarakat, atau mengangkatorang-orang dariLembaga Swadaya Masyarakat untuk menjadi pendamping dan konsultas atas hidup sehatnya masyarakat, yang pasti mereka haruslah orang yang memiliki keahlian, baik keahlian yang mengacu pada pengetahuan, keahlian yang mengacu pada pengalaman ataupun keahlian yang mengacu keterampilan dengan tetap memiliki keahlian komunikasi seperti dikemukakan Umeogu (2012).

\section{SIMPULAN}

Keahlian komunikator menyampaikan pesan tentang bahayanya HIV/AIDS telah mampu menambah pengetahuan remaja di Kecamatan Sukabumi, juga dapat menimbulkan kepercayaan remaja terhadap Konselor HIV/ AIDS serta kesediaan untuk menjauhi perilaku berisiko seperti menggunakan narkoba dan seks bebas dan kesediaan untuk mengiformasikan kepada orang lain tentang bahaya HIV/AIDS.

Kepercayaan terhadap komunikator dalam menyapaikan pesan diharapkan konselor HIV/ AIDS memiliki keterampilan khusus dalam berkomunikasi, karena disini sangat diharapkan keterbukaan dari pasien dalam menceritakan kronologis tentang penyakit yang diidapnya dan bagaimana penularannya. Daya tarik komunikator dalam menyampaikan pesan yang disampaikan oleh Konselor HIV/AIDS sangat berpengaruh yang sangat signifikan terhadap sikap remaja di Kecamatan Sukabumi.

Diharapkan Pada proses konseling, komunikasi memiliki peran penting. Komunikasi menjadi hal yang penting karena proses penyampaian pesan dilakukan melalui komunikasi. Selain itu, komunikasi juga digunakan untuk memberikan motivasi kepada remaja tentang bahayanya penyakit HIV/AIDS. Komunikasi yang tercipta antara dokter atau konselor dengan sikap dokter yang menganggap remaja itu sebagai teman/ mitra membuat posisi antara dokter atau konselor 
dan remaja tersebut menjadi seimbang, padahal dokter atau konselor disini mempunyai tingkat pengetahuan dan kompetensi yang lebih dibandingkan dengan remaja tersebut. Dengan pengalaman medisnya, dokter atau konselor lebih memahami tentang bahayanya HIV/AIDS tetapi dokter atau konselor mau melepaskan atribut "kedokterannya" untuk membuat komunikan tersebut merasa nyaman. Sikap empati seperti itulah yang ingin ditunjukkan dokter atau konselor untuk membuat konseling VCT berjalan dengan baik. Diharapkan dokter atau konselor HIV/AIDS tidak hanya untuk memberikan informasi serta memotivasi, komunikasi dalam konseling memiliki sebuah tujuan yaitu untuk mengubah sikap dan perilaku remaja tentang bahayanya HIV/ AIDS.

\section{DAFTAR PUSTAKA}

Effendy. O. (2003). Ilmu komunikasi teori dan praktek. Bandung. Remaja Rosdakarya

Kosasih, E. J., Setianti, Y., \& Wahyudin, U. (2017). Pengaruh kredibilitas petugas terhadap sikap kepatuhan pasien tbc pada pemeriksaan dahak. Jurnal Kajian Komunikasi, 5/1, 1-10

Liliweri, A. (1991). Komunikasi antarpribadi. Bandung: Citra Aditya Bakti

Peraturan Pemerintah RI. (2012). Lampiran peraturan presiden republik indonesia nomor 72 tahun 2012 tentang sistem kesehatan nasional. Jakarta

Rakhmat, J. (1998). Psikologi komunikasi. Bandung: Remaja Rosdakarya

Sarwono. (2003). Pendidikan dan perilaku seksual pranikah. Jakarta: Penerbit Grafindo

Sarwono. (2010). Ilmu kebidanan. Jakarta: Bina Pustaka

Sarwono. (2011). Psikologi remaja. Jakarta: Raja Gravido Persada

Tan. A. (1981). Mass communication theories and research. Ohio: Grid Publishing Inc., Colombus

Tinceuli. (2010). Perilaku remaja terhadap seksual pranikah. Tesis, Medan: Prodi S2 Ilmu Kesehatan Masyarakat USU

Umeogu, B. (2012). Source credibility: a philosophical analysis, Journal of Philosophy, 2012. Vol.2, No.2, 112-115

WHO. (2004). Community participation in public health. Diakses dari http://www. who.int/whr/2004/chapter3/en/index1.html

Yodiansyah, H. (2017). Komunikasi politik media surat kabar dalam studi pesan realitas politik pada media cetak riau pos dan tribun. Jurnal Kajian Komunikasi, $5 / 1(42), 11-30$ 